\title{
Extreme levels of hunting of birds in a remote village of Hainan Island, China
}

\author{
WEI LIANG, YAN CAI and CAN-CHAO YANG
}

\begin{abstract}
Summary
In China, many bird species are generally thought to be threatened mainly, or at least partly, by hunting. However, there have been few studies of bird hunting at a local scale. Bird hunting and trade in Nanmao, a remote mountainous village of Hainan Island, China, was investigated during March-July 2003 and September-October 2005. In total, 86 households were visited, of which $43 \%$ reported that they engaged in hunting of birds while $91 \%$ of households were seen to have hunted birds or hunting tools. This indicated that hunting by village people was widespread. Most hunters were male, and were between 12 and 68 years old. A total of 78 bird species were hunted, including 2 First Class and 19 Second Class national protected species. This extreme level of hunting has changed from a more moderate subsistence hunting tradition since about 1980, when local urban markets for wild meat started to develop. We outline a strategic plan designed to conserve birds, other wildlife and their forest habitats, whilst improving the livelihoods and preserving the minority tribal traditions of the people of Nanmao forest.
\end{abstract}

\section{Introduction}

The alarming loss of ecosystems and biodiversity owing to increasing human population and associated pressures on the environment can have severe consequences (Jackson et al. 2001; Lotze et al. 2006, Worm et al. 2006). Among them, overexploitation is widely regarded as a significant cause for the decline of many terrestrial vertebrate species. An unsustainable level of offtake is thought to be a primary threat for $37 \%$ of the $12 \%$ of birds threatened globally with extinction (Hilton-Taylor 2000, Baillie et al. 2004). Over-hunting and trade in wildlife are becoming two of the greatest threats to biodiversity in China (Li 2001, Zhou and Jiang 2004 a,b, Nijman 2010), particularly in cases where commercial exploitation and international trade play significant roles (Jiang, 2001, Gao and Ma, 2004, Zhou and Jiang 2004a, Zhang et al. 2008). In the China Red Data Book of Endangered Animals, 183 bird species were listed as Threatened (Zheng and Wang 1998), of which 34 species (18.6\%) were thought to be threatened mainly by hunting. An additional 56 species (30.6\%) were thought to be threatened at least partly by hunting (Zheng and Wang 1998). Hunting is generally thought to be a major threat to birds in China. There are, however, few studies of bird hunting at the local scale (e.g. Liang 1996) and those that exist are mostly concerned with the pet trade (e.g. Dai et al. 1996, Xu et al. 2002, Bi and He 2005) rather than hunting as a source of meat.

The economy of the island province of Hainan is less well developed than most others in mainland China, so the demand for pet birds is comparatively low. Thus the principal demand for wild birds is for food. This practice is an ancient tradition for subsistence among the tribal minorities on the island. Consequently local communities possess the skills to capitalise on demand for wild bird meat and are likely to play a key role in this trade. This study set out to document hunting of birds amongst one such minority group, the Miao (Hmong), in a remote mountainous area of Hainan Island by: a) determining the number and identity of species hunted and the prices obtained; and 
b) documenting hunting methods. In view of our findings, we make some suggestions about how this threat may be mitigated to improve the long term conservation prospects for Hainan's forest birds.

\section{Study area and methods}

Nanmao village and the mountain forest nearby $\left(19^{\circ} \mathrm{OO}{ }^{\prime} \mathrm{N}, 110^{\circ} \mathrm{O} 6^{\prime} \mathrm{E}\right)$ lies in the south-east of Hainan Island, China (for location of Nanmao, see Fig. I in Gong et al. 2006). The climate is seasonal with a rainy period lasting from April to October and a dry period from November to March. Annual rainfall averages $2,300 \mathrm{~mm}$ and the average annual temperature is $22^{\circ} \mathrm{C}$. The area is characterised by natural secondary forest, with broad-leaved species predominating at $800-$ $1,100 \mathrm{~m}$. Areas of higher elevation, up to $1,270 \mathrm{~m}$, are characterised by monsoon rainforest, interspersed with bamboo. The study village is situated on the mountainside at $430 \mathrm{~m}$. Up to $800 \mathrm{~m}$ above the village there are cultivated fields and plantation forests consisting mainly of rubber Hevea braziliensis and betel nut palm Areca cathecu, products of both being sold commercially.

The villagers have engaged in subsistence hunting for generations, but wildlife now provides them with a third commercial crop. Apart from birds, the villagers also hunted several globally threatened turtle species (Gong et al. 2005, 2006), as well as some mammals. At the time of these surveys, there were 86 households in the village and most practised hunting as part of the family economy (Gong et al. 2006).

The village was repeatedly visited over two periods (March-July 2003 and September-October 2005) in order to gather data on bird hunting. With the permission and assistance of the village headman, each household was visited and any birds found were identified. Hunters were also accompanied into the field when traps were visited and further information was gathered on hunted species not actually seen in the village.

\section{Results}

\section{Hunting habits}

All 86 households in the village were visited during the survey period. Only 37 households ( $43 \%$ ) reported that they were engaging in hunting of birds but 78 of the households visited $(90.6 \%)$ were seen to have hunted birds (e.g. eagle and pheasant feathers) or owned at least one type of hunting tool (see hunting methods section). This indicated that hunting by village people was widespread in the village and its nearby forest. Most hunters were male, with the eldest being 68 years old and the youngest being 12 years old in age. They went hunting when conditions permitted throughout the year, except during typhoons and heavy monsoon rains. They even hunted at night for some species, e.g. Collared Owlet Glaucidium brodiei and Greater Coucal Centropus sinensis. Although some bird species (i.e. thrushes, babblers) might be used as food in the village households, most (pheasants, eagles, owlets, coucals, pigeons and egrets) were sold by the hunters. Sales were sometimes made directly to visitors to the village, but the majority of birds were taken to local towns, where they would be sold in large batches to agents. These agents then sold the birds to market traders or directly to restaurants. Very few birds, e.g. mynahs, were sold mainly as pets, and most were sold for food.

\section{Species hunted}

Thirteen species were recorded in the village and a further 65 were confidently identified by hunters as targets, through identifying calls, visual identification in the forest, or visual identification of images in a bird identification guide (MacKinnon and Phillipps 1999) (Table 1).

Four of the species recorded directly were Galliformes, of which two were First Class protected species in China: Hainan Partridge Arborophila ardens and Hainan Peacock Pheasant Polyplectron katsumatae (Chang et al. 2008). Two others were Second Class protected species: Silver Pheasant 
Table 1 . Hunting and trade of bird species in Nanmao village, Hainan, China

Species related to trade

\begin{tabular}{lllll} 
China & IUCN Red & CITES & Price & No. \\
National & List category & Appendix & (RMB) & recorded \\
Protection & $2011^{\text {a }}$ & listing & & in village \\
class & & $2011^{b}$ & & houses \\
\hline
\end{tabular}

a) recorded directly

Hainan Partridge Arborophila ardens

Hainan Peacock Pheasant

Polyplectron katsumatae

Red Jungle fowl Gallus gallus

Silver Pheasant Lophura nycthemera

Black-browed Barbet Megalaima oorti

Greater Coucal Centropus sinensis

Emerald Dove Chalcophaps indica

Mountain Scops Owl Otus spilocephalus

Grey Nightjar Caprimulgus indicus

Black-eared Kite Milvus lineatus

Besra Sparrowhawk Accipiter virgatus

Crested Serpent-eagle Spilornis cheela

Fairy Pitta Pitta nympha

II

b) reported by hunters

Chinese Francolin Francolinus pintadeanus

Rufous Woodpecker Celeus brachyurus

Bay Woodpecker Blythipicus pyrrhotis

Lesser Yellownape Picus chlorolophus

Greater Yellownape Picus flavinucha

Lesser Coucal Centropus bengalensis

Green-billed Malkoha Phaenicophaeus tristis

Red-headed Trogon Harpactes erythrocephalus

Oriental Turtle Dove Streptopelia orientalis

Spotted Dove Streptopelia chinensis

Barred Cuckoo Dove Macropygia unchall

White-bellied Green Pigeon Treron sieboldii

Green Imperial Pigeon Ducula aenea

Mountain Imperial Pigeon Ducula badia

Eastern Grass Owl Tyto longimembris

Collared Scops Owl Otus lettia

Oriental Scops Owl Otus sunia

Collared Owlet Glaucidium brodiei

Asian Barred Owlet Glaucidium cuculoides

Blue-rumped Pitta Pitta soror

White Wagtail Motacilla alba

Grey Wagtail Motacilla cinerea

Grey-chinned Minivet Pericrocotus solaris

Scarlet Minivet Pericrocotus flammeus

Red-whiskered Bulbul Pycnonotus jocosus

Light-vented Bulbul Pycnonotus sinensis

Puff-throated Bulbul Alophoixus pallidus

Chestnut Bulbul Hemixos castanonotus

Mountain Bulbul Hypsipetes mcclellandii

Black Bulbul Hypsipetes leucocephalus

Orange-bellied Leafbird Chloropsis hardwickii

Oriental Magpie Robin Copsychus saularis
Vulnerable

Endangered $\quad 2$

II

II

II

II

II

II

II

I
I
II
II
II
II
II
II
II

\section{Least Concern}

Least Concern

Least Concern

Least Concern

Least Concern

Least Concern 2

Least Concern

$\begin{array}{cr}10 \sim 20 & 15 \\ 60 & 1 \\ & \\ 0770 / 940 & 11 \\ 07100 / 970 & 2 \\ 5 & 4 \\ 5 & 8 \\ 5 & 29 \\ 5 & 1 \\ & 2 \\ 200 & 2 \\ 100 & 1 \\ & 3 \\ 7 & 1\end{array}$

Least Concern

Least Concern

$25 \sim 35$

Least Concern

$50 / \mathrm{kg}$

$50 / \mathrm{kg}$

Least Concern

$50 / \mathrm{kg}$

$50 / \mathrm{kg}$

Least Concern

$50 / \mathrm{kg}$

Least Concern

$50 / \mathrm{kg}$

Least Concern

Least Concern

$50 / \mathrm{kg}$

Least Concern

9

9

Least Concern 2

Least Concern 8

Least Concern 20

Least Concern 20

Least Concern $\quad 15$

Least Concern 6

Least Concern 5

Least Concern $\quad 50 / \mathrm{kg}$

Least Concern $\quad 50 / \mathrm{kg}$

Least Concern $\quad 50 / \mathrm{kg}$

Least Concern $\quad 50 / \mathrm{kg}$

Least Concern $\quad 50 / \mathrm{kg}$

Least Concern $\quad 50 / \mathrm{kg}$

Least Concern $\quad 50 / \mathrm{kg}$

Least Concern $\quad 50 / \mathrm{kg}$

Least Concern $\quad 50 / \mathrm{kg}$

Least Concern $\quad 50 / \mathrm{kg}$

Least Concern $\quad 50 / \mathrm{kg}$

Least Concern $\quad 50 / \mathrm{kg}$

Least Concern $\quad 50 / \mathrm{kg}$

Least Concern $\quad 50 / \mathrm{kg}$

Least Concern $\quad 50 / \mathrm{kg}$ 
Table 1 . Continued.

Species related to trade

$\begin{array}{ll}\text { China } & \text { IUCN Red } \\ \text { National } & \text { List category } \\ \text { Protection } & 2011^{\mathrm{a}} \\ \text { class } & \end{array}$

A

White-rumped Shama Copsychus malabaricus

White-crowned Forktail Enicurus leschenaulti

Common Blackbird Turdus merula

Japanese Thrush Turdus cardis

Yellow-browed Warbler Phylloscopus inornatus

Asian Brown Flycatcher Muscicapa dauurica

Hainan Blue Flycatcher Cyornis hainanus

White-throated Fantail Rhipidura albicollis

Black-naped Monarch Hypothymis azurea

Lesser Necklaced Laughingthrush

Garrulax monileger

Greater Necklaced Laughingthrush

Garrulax pectoralis

Black-throated Laughingthrush

Garrulax chinensis

Grey Laughingthrush Garrulax maesi

Hwamei Garrulax canorus

Large Scimitar Babbler Pomatorhinus hypoleucos

Streak-breasted Scimitar Babbler

Pomatorhinus ruficollis

Rufous-capped Babbler Stachyris ruficeps

Grey-cheeked Fulvetta Alcippe morrisonia

White-bellied Erpornis Erpornis zantholeuca

Great Tit Parus major

Rufous-faced Warbler Abroscopus albogularis

Grey-headed Parrotbill Paradoxornis gularis

White-rumped Munia Lonchura striata

Scaly-breasted Munia Lonchura punctulata

Fork-tailed Sunbird Aethopyga christinae

Japanese White-eye Zosterops japonicus

Long-tailed Shrike Lanius schach

Ashy Drongo Dicrurus leucophaeus

Bronzed Drongo Dicrurus aeneus

Greater Racket-tailed Drongo

Dicrurus paradiseus

Yellow-breasted Magpie Cissa hypoleuca

Grey Treepie Dendrocitta formosae

Crested Myna Acridotheres cristatellus

\begin{tabular}{|c|c|c|}
\hline Least Concern & $50 / \mathrm{kg}$ & \\
\hline Least Concern & $50 / \mathrm{kg}$ & \\
\hline Least Concern & $50 / \mathrm{kg}$ & \\
\hline Least Concern & $50 / \mathrm{kg}$ & \\
\hline Least Concern & $50 / \mathrm{kg}$ & \\
\hline Least Concern & $50 / \mathrm{kg}$ & \\
\hline Least Concern & $50 / \mathrm{kg}$ & \\
\hline Least Concern & $50 / \mathrm{kg}$ & \\
\hline Least Concern & $50 / \mathrm{kg}$ & \\
\hline Least Concern & $50 / \mathrm{kg}$ & \\
\hline Least Concern & $50 / \mathrm{kg}$ & \\
\hline Least Concern & $50 / \mathrm{kg}$ & 1 \\
\hline Least Concern & $50 / \mathrm{kg}$ & \\
\hline Least Concern 2 & $50 / \mathrm{kg}$ & \\
\hline Least Concern & $50 / \mathrm{kg}$ & \\
\hline Least Concern & $50 / \mathrm{kg}$ & \\
\hline Least Concern & $50 / \mathrm{kg}$ & \\
\hline Least Concern & $50 / \mathrm{kg}$ & \\
\hline Least Concern & $50 / \mathrm{kg}$ & \\
\hline Least Concern & $50 / \mathrm{kg}$ & \\
\hline Least Concern & $50 / \mathrm{kg}$ & \\
\hline Least Concern & $50 / \mathrm{kg}$ & \\
\hline Least Concern & $50 / \mathrm{kg}$ & \\
\hline Least Concern & $50 / \mathrm{kg}$ & \\
\hline Least Concern & $50 / \mathrm{kg}$ & \\
\hline Least Concern & $50 / \mathrm{kg}$ & \\
\hline Least Concern & $50 / \mathrm{kg}$ & \\
\hline Least Concern & $50 / \mathrm{kg}$ & \\
\hline Least Concern & $50 / \mathrm{kg}$ & \\
\hline Least Concern & $50 / \mathrm{kg}$ & \\
\hline Least Concern & 3 & \\
\hline Least Concern & 3 & \\
\hline Least Concern & 3 & \\
\hline
\end{tabular}

${ }^{a}$ IUCN Red List categories 2011: http://www.iucnredlist.org (accessed on 6 July 2011);

${ }^{\mathrm{b}}$ CITES Appendix listing 2011: http://www.cites.org/eng/app/index.shtml (accessed on 6 July 2011).

Lophura nycthemera and Red Junglefowl Gallus gallus. A further six Second Class protected species were recorded, including three diurnal raptors and an owl. All these species were usually sold dead as they had been leg-trapped and had died before being retrieved from traps.

Many of the hunters claimed that after the outbreak of SARS in 2003 (Wang et al. 2003), the trade in some species of mammals (e.g. masked palm civet Paguma larvata) collapsed, further increasing the demand for birds, with larger species such as pheasants, raptors and pigeons being especially popular. 


\section{Hunting methods}

People in the village used several kinds of hunting tools, including shotguns, air-rifles, metal leg traps, pinchers, bamboo leg hold traps, bamboo cages, pitfalls and electric devices. All of the above hunting tools were purchased by hunters in local towns. Additional traps were manufactured in the villages from local materials. Shotguns were long-barrelled $(1.5 \mathrm{~m})$ muzzle-loaders, firing steel or lead shot with a diameter of $2-3 \mathrm{~mm}$ or $6-8 \mathrm{~mm}$. The smaller shot was used for small birds and mammals, while the larger shot was reserved for the largest birds and mammals. Shot cost $6 \mathrm{RMB} / \mathrm{kg}$ at the time of the survey (\$100 was equivalent to about $650 \mathrm{RMB}$ ). Air-rifle pellets were mushroom-shaped and $5 \mathrm{~mm}$ in length. They were sold for $4.5 \mathrm{RMB} / 12 \mathrm{O}-150$ pellets and were used exclusively for killing small birds. Both shot and pellets were sold in the general store in the village.

There were two kinds of metal leg traps: large ones (diameter $30 \mathrm{~cm}$ ) with saw-teeth on two jaws that spring together to catch large mammals, and smaller 'pinch' traps (diameter $10 \mathrm{~cm}$ ) of similar design used for trapping rodents and birds.

Leg snares were of variable size according to the intended prey. Larger ones were aimed at large mammals, while smaller ones were directed especially at pheasants and partridges. The leg traps were sprung by a $1.2-1.5 \mathrm{~m}$ bamboo cane. They were designed for catching smaller mammals, reptiles, and birds which live mainly on the ground. Both bamboo cage and pitfall traps were made exclusively for catching turtles and mammals. The spring leg traps and metal leg traps often catch birds. They are capable of trapping pheasants, pigeons, coucals, pittas, laughing-thrushes and even raptors.

\section{Discussion}

The study showed that, even in a remote village of Hainan island, China, hunting of birds at a local scale was amazingly high. Conversations with the villagers suggest that until about 1980, wildlife resources were abundant. Hunters just used shotguns to kill large mammals such as deer and wild boar for their own consumption. Subsequently, some villagers began to sell wildlife in local towns but the price was low (1.2 RMB/kg). As the standard of living improved for town-dwellers, people became more interested and able to purchase wildlife for culinary uses, and prices rose. For example, the prices for wild boar, deer and cobra at the time of the survey were $40 \mathrm{RMB} / \mathrm{kg}$, $60 \mathrm{RMB} / \mathrm{kg}$ and $260 \mathrm{RMB} / \mathrm{kg}$, respectively. The profits to be made led to unrestrained hunting all year round and at night. Although the public selling of wild species has been illegal under Chinese law since 1988, a prosperous black market has developed since, and the illicit trade continues unabated.

Thus many species of birds have now become hunting quarry in the village and the forest nearby. Amongst them, the two coucal species (Greater Coucal and Lesser Coucal Centropus bengalensis) are noteworthy for their popularity. This situation arises because they are consumed very widely in Hainan as a supposed tonic, whilst also being soaked in local alcoholic liquor to produce a traditional Chinese medicine. Of all bird species, only the Barn Swallow Hirundo rustica and three swift species Apus spp. are deliberately spared by the hunters: they hold a special place in local customs, and in Hainan society in general, partly because they build their nests on houses and are therefore cherished in traditional culture. These observations imply that, for a small number of species, traditional culture can play a role in the conservation of birds and other wildlife at the local or regional scale.

The impact of hunting is being exacerbated by habitat destruction. The area around the village is still being used for slash and burn agriculture. However there is now a tendency to plant rubber trees and betel nut palms as long term, low maintenance and profitable crops, rather than allow areas to return to forest after a few years use for food crops. Numerous areas that had been recently burnt but not used for cultivation of crops were observed. Due to farming activities and human disturbance, many species of bird are now restricted to the higher parts of Nanmao forest. 
Our field survey indicated that the Hainan Partridge is still present in the bamboo forest at 60o-70o m and in the evergreen broad-leaved forest higher up the slope. The partridges occur at greatest density in the monsoon rainforest close to the ridge-top where one of six partridges carrying a transmitter as part of our research was shot by a local hunter. Despite the remoteness of these habitats from the village, and the extreme density of ground vegetation, we found hundreds of leg snares in this area, and had to stop the partridge radio-tracking research in this area.

\section{Recommendations}

In view of our findings, we make the following suggestions for mitigation of this threat to improve the long term conservation prospects for Hainan's forest birds and their habitats.

First, the only way for the forest to maintain populations of the First and Second Class stateprotected bird species, including the two endemic species, the Hainan Partridge and Hainan Peacock Pheasant, will be establishment of a Nature Reserve and enforcement of the associated laws designed to protect wildlife and its habitats (Primack and Ji 2000).

Second, the conflict between biodiversity conservation and the exploitation of natural resources by local people needs to be addressed. The standard of living in the village is low, and the income derived from the sale of wildlife is both financially crucial to households and the prime cause of over-hunting in the area. As a means of generating income by alternative ways, the villagers should be assisted to maximise profits from growing crops and supplying minority artefacts (e.g. traditional garments) to the burgeoning tourist industry. Local people should also be given priority for employment in the nature reserve, so that they can maintain a link with their ancestral landscape. They can offer uniquely well-informed guidance to visitors, many of whom will be unfamiliar with their cultural heritage, the tropical rainforest and its wildlife species.

Third, the effectiveness of any management initiatives undertaken in the Nature Reserve can only be judged by monitoring some indicators of ecological health from amongst the wildlife species and habitats present. In this case the Hainan partridge might be promoted as a flagship (Liang et al. 2002) for the Nature Reserve as well as a species for annual monitoring. It calls distinctively at dawn during the breeding season (Yang et al. 2011), enabling counts to be repeated systematically. It is a prime target for hunters as well as being highly sensitive to human disturbance and habitat degradation (Cai et al. 2009). Only through effective management of the Nature Reserve will the partridge population remain stable, or possibly increase.

\section{Acknowledgements}

We thank Jichao Wang, Shiping Gong, Youli Fu and Yunfang Hu for their help in the survey, and the Forestry Department of Hainan Province for support and permission to carry out the study. Dr Peter Garson and Dr. Philip McGowan kindly helped with improving the English text. Dr Richard Fuller and Prof. Stephen Garnett provided helpful suggestions that improved the manuscript. This research was funded by National Science Foundation of China (No. 30360015 and No.30860044), National Geographic Society (NGS) Conservation Trust (C66-05), WWF-China Small Grant (CNo861.01) and by Program for New Century Excellent Talents in University (NCET-IO-O111).

\section{References}

Baillie, J. E. M., Hilton-Taylor, C. and Stuart, S. N., eds. (2004) 2004 IUCN Red List of threatened species. A global species assessment. Gland, Switzerland and Cambridge, UK: IUCN.

$\mathrm{Bi}, \mathrm{J} . \mathrm{H}$. and He, X. P. (2005) An investigation on the trade of wild birds market in
Huhhot. J. Inner Mongolia Normal Univ. (Nat. Sci). 34: 93-101.

Cai, Y., Yang, C. C. and Liang, W. (2009) Negative effects of plantations on bird diversity in Yinggeling Nature Reserve, Hainan Island. Sichuan J. Zool. 28:764767. 
Chang, J., Wang, B., Zhang, Y. Y., Liu, Y. Y., Liang, W., Wang, J. C., Shi, H. T., $\mathrm{Su}$, W. B. and Zhang, Z. W. (2008) Molecular evidence for species status of the endangered Hainan Peacock Pheasant. Zool. Sci. 25: 30-35.

Dai, B., Zhang, L. M. and Zhang, G. X. (1996) Market investigation of birds for viewing. Sichuan J. Zool. 25: 29-31.

Gao, Z. C. and Ma, J. Z. (2004) The trade and the protection of wildlife. Territory \& Natural Resources Study 1: 85-86.

Gong, S. P., Fu, Y. L., Wang, J. C., Shi, H. T. and $\mathrm{Xu}, \mathrm{R} . \mathrm{M}$. (2005) Freshwater turtle trade in Hainan and suggestions for effective management. Biodivers Sci. 13: 239-247.

Gong, S. P., Wang, J. C., Shi, H. T., Song, R. H. and $\mathrm{Xu}, \mathrm{R}$. M. (2006) Illegal trade and conservation of freshwater turtles in Nanmao Village, Hainan Province, China. Oryx 40: 331-336.

Hilton-Taylor, C., compiler. (2000) 2000 IUCN Red List of threatened species. Gland, Switzerland, and Cambridge, UK: IUCN.

Jackson, J. B. C., Kirby, M. X., Berger, W. H., Bjorndal, K. A., Botsford, L. W., Bourque, B. J., Bradbury, R. H., Cooke, R., Erlandson, J., Estes, J. A., Hughes, T. P., Kidwell, S., Lange, C. B., Lenihan, H. S., Pandolfi, J. M., Peterson, C. H., Steneck, R. S., Tegner, M. J. and Warner, R. R. (2001) Historical overfishing and the recent collapse of coastal ecosystems. Science 293: 629-638.

Jiang, Z. G. (2001) Economic extinction and trade control of wild fauna and floratraditional biology research and the nature conservation law and policy-making. World Sci-Tech Res. \& Dev. 23: 28-32.

Li, Y. M. (2001) Advances in game hunting, wildlife trade and hunting sustainability. Biodivers Sci. 9: 414-421.

Liang, W. (1996) Investigation on hunting for the pheasant in the Leigong Mountain area, Guizhou Province, China. Chin. Wildl. 5: 9-13.

Liang, W., Shi, H. T. and Wang, L. J. (2002) A discussion on the Hainan provincial birds. J. Hainan Normal Univ. (Nat. Sci.) 15: $67-70$.

Lotze, H. K., Lenihan, H. S., Bourque, B. J., Bradbury, R. H., Cooke, R. G., Kay, M. C.,
Kidwell, S. M., Kirby, M. X., Peterson, C. H. and Jackson, J. B. C. (2006) Depletion, degradation, and recovery potential of estuaries and coastal seas. Science 312: 18061809.

MacKinnon, J. and Phillipps, K. (1999) A field guide to the birds of China. Oxford, UK: Oxford University Press.

Nijman, V. (2010) An overview of international wildlife trade from Southeast Asia. Biodivers Conserv. 19: 1101-1114.

Primack, R. and Ji, W. Z. (200o) A primer of conservation biology. Beijing: China Forestry Press.

Wang, W., Huang, Y., Zhou, W. Q., Qiao, L., Huang, J. H., Hu, X. A., Yu, Z., Liu, Q. H. and $\mathrm{Wu}, \mathrm{Z}$. L. (2003) An outbreak of SARS in Dongcheng District, Beijing during March to June 2003. Acta Academicae Medicinae Sinicae 25: 533-538.

Worm, B., Barbier, E. B., Beaumont, N., Duffy, J. E., Folke, C., Halpern, B. S., Jackson, J. B. C., Lotze, H. K., Micheli, F., Palumbi, S. R., Sala, E., Selkoe, K. A., Stachowicz, J. J. and Watson, R. (2006) Impacts of biodiversity loss on ocean ecosystem services. Science 314: 787-790.

$\mathrm{Xu}$, J. L., Zhang, Z. W. and Zhang, S. P. (2002) Investigation of the bird markets in Tianjin. J. Beijing Normal Univ. (Nat. Sci.) 38: 535-539.

Yang, C. C., Zhang, Y. Y., Cai, Y., Stokkle, B. G. and Liang, W. 2011. Female crowing and differential responses to simulated conspecific intrusion in male and female Hainan Partridge (Arborophila ardens). Zool. Sci. 28: 249-253.

Zhang, L., Hua, N. and Sun, S. (2008) Wildlife trade, consumption and conservation awareness in southwest China. Biodivers. Conserv. 17: 1493-1516.

Zheng, G. M. and Wang, Q. S. (1998) China Red Data Book of endangered animals: Aves. Beijing: Science Press.

Zhou, Z. H. and Jiang, Z. G. (2004a) Dynamics of the international trade in wild fauna and flora in China. Scientia Silvae Sinicae 40: $151-156$.

Zhou, Z. H. and Jiang, Z. G. (2004b) International trade status and crisis for snake species in China. Conserv. Biol. 18: 13861394. 
WEI LIANG*, YAN CAI

College of Life Sciences, Hainan Normal University, Haikou 571158, China.

CAN-CHAO YANG

College of Life Sciences, Hainan Normal University, Haikou 571158, China and State Key Laboratory of Biocontrol, School of Life Sciences, Sun Yat-sen University, Guangzhou 510275, China.

*Author for correspondence; e-mail: liangwei@hainnu.edu.cn

Received 19 September 2010; revision accepted 23 August 2011;

Published online 16 December 2011 